\title{
Pengembangan Media Pembelajaran Multimedia Interaktif Dengan Model Hannafin And Peck Bermuatan Ipa Kelas IV
}

\section{Made Pebiana Saputra ${ }^{1 *}$, DB. Kt. Ngr Semara Putra²}

${ }^{12}$ Prodi Pendidikan Guru Sekolah Dasar, Universitas Pendidikan Ganesha, Singaraja, Indonesia *e-mail: Imadepebianasaputra27@Undiksha.ac.id

\begin{abstract}
Abstrak
Kurangnya media pembelajaran sehingga siswa kurang mampu memahami materi pembelajaran secara maksimal. Penelitian ini bertujuan untuk mengambarkan rancang bangun dan validitas pengembangan media pembelajaran multimedia interaktif pada kelas IV SD muatan. Penelitian ini dikembangkan menggunakan model pengembangan Hannafin and Peck yang meliputi tiga tahapan, yaitu (a) penilaian kebutuhan, (b) desain/perancangan, (c) pengembangan dan implementasi. Subjek penelitian berjumlah 9 orang peserta didik kelas IV. Metode pengumpulan data yang digunakan adalah observasi, wawancara, dan angket. Instrumen penelitian terdiri dari lembar angket penilaian produk. Teknik analisis data yaitu analisis deskriptif kualitatif dan deskriptif kuantitatif. Tahap pengujian kelayakan media ini dilakukan dengan cara validasi produk oleh pakar. Hasil penelitian menunjukkan bahwa nilai validitas produk dengan kategori sangat baik dengan: (a) Hasil review ahli isi mata pelajaran menunjukkan hasil sangat baik $(92,8 \%)$, (b) Hasil review ahli desain pembelajaran dengan hasil sangat baik $(92,8 \%)$, (c) Hasil review ahli media pembelajaran menunjukkan hasil sangat baik $(93,1 \%)$, (d) Hasil uji coba perorangan sangat baik $(94,2 \%)$, hasil uji coba kelompok kecil dengan hasil baik $(89,75 \%)$. Implikasi penelitian ini dapat mrmbuat siswa menjadi tertarik dengan materi yang diberikan. Berdasarkan hasil yang diperoleh dapat disimpulkan bahwa media pembelajaran multimedia interaktif ini sangat baik digunakan dalam proses pembelajaran.
\end{abstract}

Kata kunci: pengembangan, multimedia interaktif, hannafin and peck

\begin{abstract}
Lack of learning media so that students are less able to understand the learning material optimally. This study aims to describe the design and validity of the development of interactive multimedia learning media in grade IV SD content. This research was developed using the Hannafin and Peck development model which includes three stages, namely (a) needs assessment, (b) design / design, (c) development and implementation. The research subjects were 9 grade IV students. Data collection methods used were observation, interviews, and questionnaires. The research instrument consisted of a product assessment questionnaire sheet. The data analysis technique is descriptive qualitative analysis and quantitative descriptive analysis. This media feasibility testing phase is carried out by validating the product by experts. The results showed that the product validity value was categorized as very good with: (a) The results of the subject content expert review showed very good results (92.8\%), (b) The results of the learning design expert review with very good results (92.8\%), (c) The results of the review of instructional media experts showed very good results (93.1\%), (d) The results of individual trials were very good (94.2\%), the results of small group trials with good results (89.75\%). The implication of this research can make students interested in the material given. Based on the results obtained, it can be concluded that this interactive multimedia learning media is very well used in the learning process.
\end{abstract}

Keywords: development, interactive multimedia, hannafin and peck

\footnotetext{
${ }^{*}$ Corresponding author.

Received 30 Januari 2021; Accepted 1 Maret 2021; Available online 8 April 2021 (C) 2021 MI All Rights Reserved
} 


\section{Pendahuluan}

Pendidikan merupakan faktor penting yang harus dimiliki oleh setiap orang. Pendidikan merupakan suatu upaya yang telah terorganisasi anak didik menjadi dewasa (Susanto, 2015; Sutrisno, 2016). Salah satu kegiatan pendidikan yaitu pembelajaran. Pembelajaran merupakan bagian inti dari suatu proses pendidikan yang dilaksanakan di sekolah. Pembelajaran merupakan sistem yang berupa gabungan dari koponen-koponen yang berhubungan satu sama lain untuk mencapai tujuan pembelajaran (Dolong, 2016 ; Rusman, 2017). Salah satu pembelajaran di sekolah dasar yang paling kompleks adalah pembelajaran tematik. Pembelajaran tematik merupakan suatu pembelajaran tepadu untuk mengaitkan beberapa mata pelajaran berpendekatan tematik yang didasarkan pada sebuah tema serta diterapkan oleh pemerintah untuk jenjang pendidikan sekolah dasar (Akrim, 2018; Anshory, 2020; Ananda, 2018). IImu Pengetahuan Alam (IPA) adalah salah satu muatan dari pembelajaran tematik. IPA adalah cabang ilmu yang mempelajari peristiwa-peristiwa yang terjadi di alam sebagai latihan awal peserta didik berpikir dalam mengembangkan daya ciptanya (Kudisiah, 2018). Pokok bahsan metamorfosis adalah salah satu pokok bahasan pada materi IPA. Metamorfosis merupakan proses perkembangan pada hewan yang melibatkan perubahan penampilan dan atau struktur setelah kelahiran (Wahyudi, 2018; Nugroho,dkk, 2014). Untuk mencapai tujuan pembelajaran IPA dengan lebih optimal, maka diperlukan suatu media pembelajaran. Media pembelajaran merupakan sebuah alat bantu dalam proses pembelajaran yang bertujuan untuk memperjelas makna yang tersirat dalam materi yang diajarkan agar lebih baik (Kustandi \& Darmawan, 2020; Adam, 2015) Dengan menggunakan media pembelajaran yang sesuai dengan kodisi dan situasi, maka beberapa mas alah dalam pembelajaran dapat diatasi.

Permasalahan yang terjadi saat ini yaitu banyak siswa yang tidak memahami materi pembelajaran disebabkan oleh kurangnya media pembelajaran yang memfasilitasi siswa dalam belajar. Kurangnya media pembelajaran ini berdampak pada pemahaman materi pembelajaran yang rendah (Herayanti, Habibi, \& Fuaddunazmi, 2017; Wulandari, Sudatha, \& Simamora, 2020). Permasalahan ini juga terjadi pada salah satu sekolah dasar. Berdasarkan hasil observasi, penyebaran angket karakteristik siswa dan wawancara kepada guru wali kelas IV yang dilakuakan di sekolah dasar ditemukan hasil bahwa dalam melaksanakan pembelajaran secara dalam jaringan sudah memanfaatkan beberapa jenis media pembelajaran elekteronik seperti; Whatapps, Google classroom, blog, dan, Youtube. Selain itu media pembelajaran yang nyata juga dengan mengubahnya menjadi video yang sesuai dengan materi yang akan diajarkan. Siswa di sekolah dasar rata-rata menggunakan handphone untuk mengkuti pembelajaran dalam jaringan. Awalnya penggunaan media elektronik tersebut mendapatkan respon yang baik pada beberapa siswa, meskipun pada awal penerapannya ada beberapa kendala yang dialami baik dari guru, siswa, maupun orang tua siswa. Setelah beberapa minggu diterapkan siswa semakin aktif dalam mengikuti pembelajaran daring karena sudah banyak yang bisa memakai media elektronik seperti handphone, namun setalah berjalan lebih lama ditemukan masalah baru yaitu siswa menjadi bosan karena mereka hanya menonton dan membaca materi pembelajaran tanpa banyak interaksi yang terjadi saat belajar dan sudah mulai bosan dengan media yang digunkan. Hal tersebut menyebabkan banyak tujuan pembelajaran tidak tersampaikan dengan baik, salah satu diantaranya adalah muatan pelajaran IPA dengan pokok bahasan metamorfosis. Dengan kata lain permasalahan yang terjadi di sekolah dasar adalah kebosanan yang dihadapi oleh siswa akibat penggunaan media pembelajaran yang sama terus menerus dan kurang cocok untuk digunakan pada pembelajaran dalam jarigan karena kurangnya interaktifitas.

Adanya kesenjangan antara kondisi nyata dengan kondisi yang diharapkan, maka jika tidak ditindaklanjuti dikhawatirkan dapat berdampak terhadap rendahnya motivasi, 
minat, serta hasil belajar siswa itu sendiri. Salah satu cara yang dapt ditempuh adalah memilih dan mengembangakan media pembelajaran yang sesuai dengan situasi sekarang ini. Masalah yang ditemukan tersebut dapat diatasi dengan menggunakan media pembelajaran Multimedia interaktif berbentuk aplikasi android. Hal ini sesuai dengan penelitian yang mengatakan bahwa media pembelajaran mempermudah siswa dalam hal belajar (Puspitorini, Subali, \& Jumadi, 2014; Supriyono, 2018). Salah satu pembelajaran di sekolah dasar yang sangat memerlukan media pembelajaran adalah tematik khususnya pada muatan pelajaran IPA. Sesuai pendapat yang mengmukakan bahwa pembelajaran IPA seharusnya bervariasi dari model maupun strategi yang digunakan untuk mengoptimalkan strategi belajar dari masing-masing siswa (Wijanarko, 2017; Yuliati, 2017). Pendapat lain juga memperkuat penyataan tersebut dengan pendapatnya bahwa pembelajaran IPA sulit dipelajari dengan hanya menggunakan buku, sehingga diperlukan suatu media pendukung (Isdayanti, 2020). Media pembelajaran yang digunakan juga harus membuat siswa melakukan inetraksii dalam penggunaanya. Sejalan dengan pendapat yang berpendapat bahwa IPA berkaitan dengan cara sistematis, sehingga bukan hanya penguasaan kumpulan pengetahuan berupa fakta dan konsep, atau prinsip-prinsip saja tetapi juga merupakan suatu proses penemuan (Tias, 2017). Selain itu pada saat pembelajaran dalam jaringan media yang digunakan juga harus menarik dan tidak menghabiskan banyak waktu. Seperti pendapat yang mengungkapkan bahwa penggunaan media dapat menyamapaikan materi pembelajaran dengan seragam, serta lebih menarik, interatif dan dapat menghemat waktu (Melianti, 2020; Rahmi, Budiman, \& Widyaningrum, 2019).

Selain itu penelitian sebelumnya juga mendukung penggunaan multimedia untuk mengatasi permasalah dalam pembelajaran. Seperti penelitian yang mengembangkan media pembelajaran multimedia dalam bentuk konkret di sekolah dasar oleh (Pratama, 2017) yang mendapatkan hasil multimedia interaktif yang di kembangkan efektif untuk meningkatkan hasil belajar IPA peserta didik kelas V. Penelitian lain yang serupa dilakukan pada tahun berikutnya oleh Kuswanto \& Walusfa (2017) dengan hasil penelitiannya yang menyatakan bahwa multimedia yang dikembangkan dapat diterapkan untuk meningkatkan pemahaman siswa dalam belajar. Penelitian lain yang serupa juga dilakukan oleh Diartha, Sudarma, \& Suwatra, (2019a) menyatakan bahwa multimedia pembelajaran efektif untuk meningkatkan hasil belajar IPA di SD Mutiara Singaraja. Penelitian dengan mengembangkan multimedia pembelajaran interaktif juga pernah dilakuakn di jenjang pendidikan yang lebih tinggi, seperti penelitian yang dilakukan oleh Asto (2015) dengan hasil penelitiannya menyebutkan media pembelajaran interaktif berbantuan software Macromedia Flash pada kompetensi dasar menerapkan macammacam gerbang dasar rangkaian logika baik dan layak digunakan sebagai media dalam proses pembelajaran.

Penelitian ini bertujuan untuk mengembangkan sebuah media pembelajaran multimedia interaktif dengan mendeskripsikan rancang bangun dan validasi media yang dikembangkan. Penelitian ini sangat penting dilaksanakan mengingat bahawa materi IPA akan lebih mudah dipahami siswa apabila dibantu dengan menggunakan media pembelajaran. Dengan mengembangkan media pembelajaran multimedia interaktif akan dapat membuat tuntutan pembelajaran IPA tercapai dengan lebih baik. Pembelajaran dalam jaringan membuat guru kesulitan untuk menyampaikan meteri pembelajaran kepada siswa, sehingga dengan mengembangankan media pembelajaran multimedia iteraktif masalah tersebut dapat diatasi.

\section{Metode}

Dalam penelitian pengembangan ini, peneliti menggunakan model pengembangan Hannafin dan Peck. Model ini terdiri dari tiga tahap utama sehingga akan lebih mudah dipahami dan dikembangkan dalam waktu yang singkat namun dengan evaluasi dan revisi pada setiap tahapannya akan membuat model pengembangan ini akan tetap 
berjalan ke arah yang diinginkan. Model Hannafin and Peck terdiri atas tiga langkah, yaitu penilaian kebutuhan (need assessment), desain (pengembangan dan implementasi (development \& implementation), serta dalam setiap tahap melalui proses evaluasi dan revisi (Tegeh,dkk, 2014). Model Hannafin dan Peck digambarkan sebagai berikut.

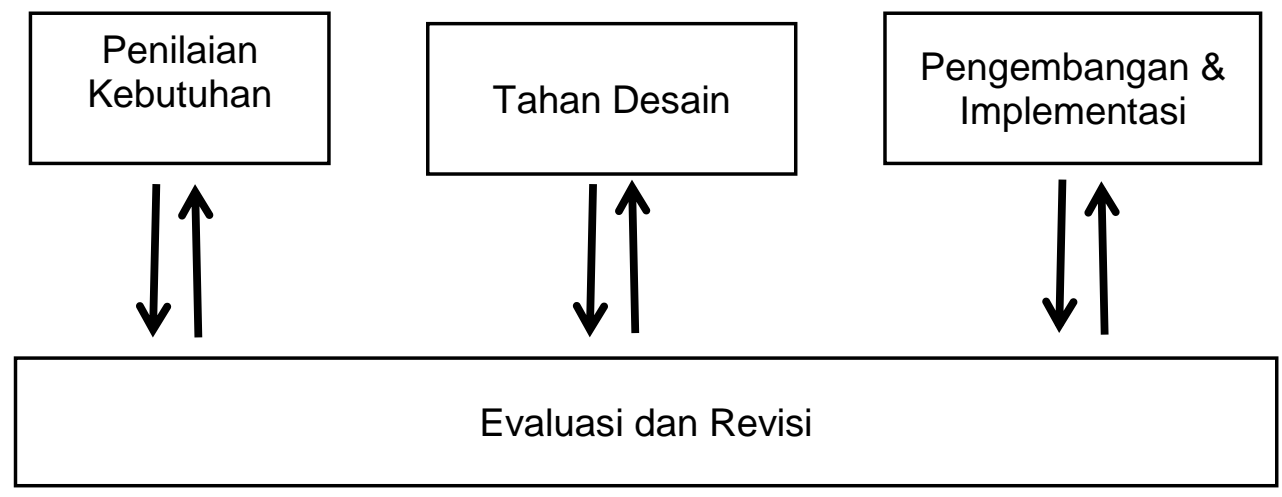

Gambar 1. Model Pengembangan Hannafin and Peck

Pada tahap penilaian kebutuhan yang dilakukan adalah penilaian terhadap kebutuhan-kebutuhan dalam pengembangan suatu produk atau media pembelajaran. Setelah melakukan penilaian, hasil tersebut dikonusultasikan terlebih dahulu kepada guru kelas untuk menerima masukan dan saran. Pada tahap desain pengembangan difokuskan pada rancangan media pembelajaran berupa rancangan flowchart dan storyboard. Flowchart disebut juga bagan alir yang merupakan representasi grafik dari sebuah suatu algoritma atau prosedur guna menyelesaikan suatu masalah (Lasminiasih, 2016). Tahap ketiga adalah tahap pengembangan dan implementasi yang meliputi kegiatan memadukan, mengembangkan, maupun membuat program pembelajaran yang baru. Setelah itu produk pembelajaran yang sudah dikembangkan kemudian dievaluasi dan direvisi oleh dosen pembimbing serta pakar ahli sehingga diperoleh perangkat yang sesuai dengan kebutuhan serta dapat diimplementasikan dalam proses pembelajaran secara langsung

Subjek uji coba yang dilaksanakan pada penelitian ini yaitu seorang ahli isi mata pelajaran, seorang ahli desain dan media pembelajaran. Selain iti dilakukan juga uji coba perorangan dengan subjek tiga orang siswa dengan satu oarang siswa berprestasi tinggi, satu orang siswa berprestasi sedang dan satu orang siswa berprestasi rendah. Selain itu ada enam orang siswa dengan dua oarng siswa berprestasi tinggi, dua orang siswa berprestasi sedang dan dua orang siswa berprestasi rendah sebagai subjek uji coba kelompok kecil. Dalam penelitian pengembangan ini digunakan dua teknik analisis data, yaitu (1) metode analisis deskriptif kualitatif dan metode analisis deskriptif kuantitatif. Instrumen yang digunakan pada penelitian ini adalah lembar kuisioner untuk penilaian oleh pakar ahli. Penelitian Pengembangan menggunakan tiga metode pengumpulan data untuk menjawab permasalahan mengenai proses pengembangan media pembelajaran multimedia interaktif yaitu, metode wawancara, kuesioner/angket dan observasi.

Jenis data pada penelitian ini adalah data kualitatif dan data kuantitatif. Data kualitatif berupa data yang berupa kata atau kalimat seperti kriteria ; Sangat Setuju (SS), Setuju (S), Tidak Setuju (TS), Sangat Tidak Setuju (STS). Data kuantitatif berupa skor dari penilaian ahli isi mata pelajaran, ahli desain pembelajaran, ahli media pembelajaran, uji coba perorangan, dan uji coba kelompok kecil yang berupa angka yang didapat dengan mengubah data kuanlitatif menggunakan skala linkert sehingga diperoleh data dalam bentuk angka. 


\section{Hasil dan Pembahasan}

Rancang bangun penelitian ini menggunakan model Hannafin and Peck. Hasil yang didapatkan pada tahap pertama dari model ini adalah tahap penilaian kebutuhan. Pada tahap ini hal yang dilakukan adalah penilaian terhadap kebutuhan-kebutuhan dalam pengembangan suatu produk atau media pembelajaran. Dari hasil observasi kesekolah, penyebaran angket karakteristik siswa, dan mengamati guru mengajar dalam jaringan ditemukan bahwa sekolah sudah memiliki fasilitas yang cukup memadai dan guru pun sudah mahir menggunakan teknologi untuk melakukan pembelajaran dalam jaringan. Guru sudah menggunkan media pembeljaran elektronik seperti Whatapps, Google classroom, blog, dan, Youtube. Namun setelah beberapa lama ditemukan masalah dimana siswa merasa bosan dengan media pembelajaran yang monoton dan kurangnya interaktifitas pada media yang digunakan.

Tahap desain merupakan tahap yang kedua dalam model pengembangan Hannafin and Peck. Pada tahap ini pengembangan ini lebih difokuskan pada upaya untuk memasukkan masalah kesenjangan pembelajaran yang terjadi pada tahap sebelumnya kemudian dituangkan pada rancangan media pembelajaran berupa rancangan flowchart dan storyboard. Rancangan yang sudah dibuat tersebut dikonsultasikan terlebih dahulu kepada dosen pembimbing untuk menerima masukan dan saran untuk menyempurnakan rancangan tersebut. Berikut gambar rancangan yang dibuat.

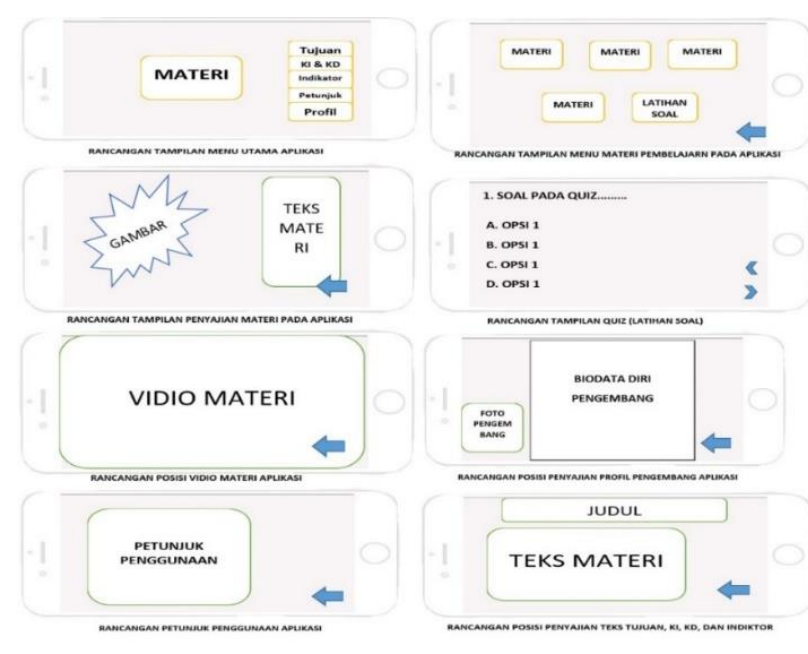

Gambar 2. Storyboard

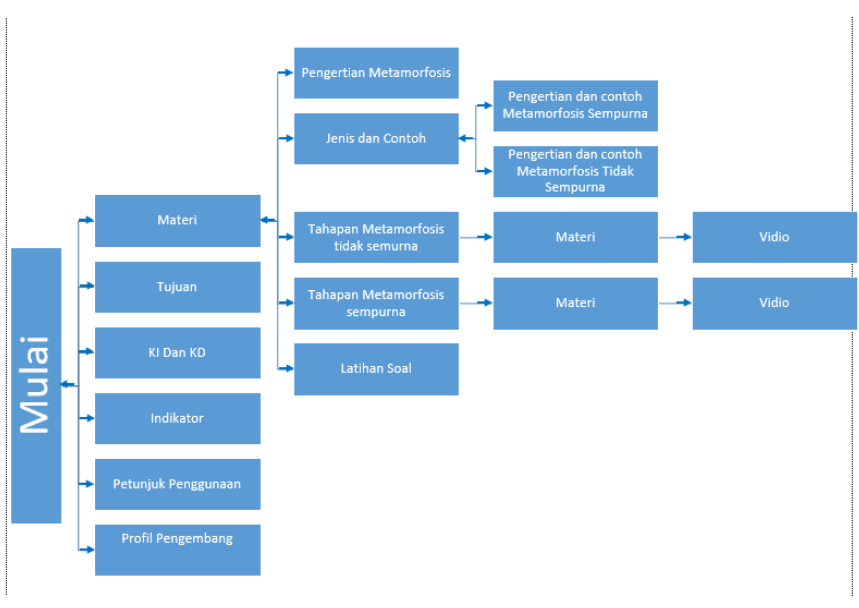

Gambar 3. Flowchart 
Tahap ketiga adalah tahap pengembangan dan implementasi yang meliputi kegiatan memadukan, mengembangkan, maupun membuat program pembelajaran yang baru. Setelah itu produk pembelajaran yang sudah dikembangkan kemudian dievaluasi dan direvisi oleh dosen pembimbing dan pakar ahli, sehingga diperoleh perangkat yang sesuai dengan kebutuhan serta dapat diimplementasikan dalam proses pembelajaran secara langsung. Berikut beberapa tangkapan layar dari aplikasi yang telah dikembangkan disajikan pada gambar 4.
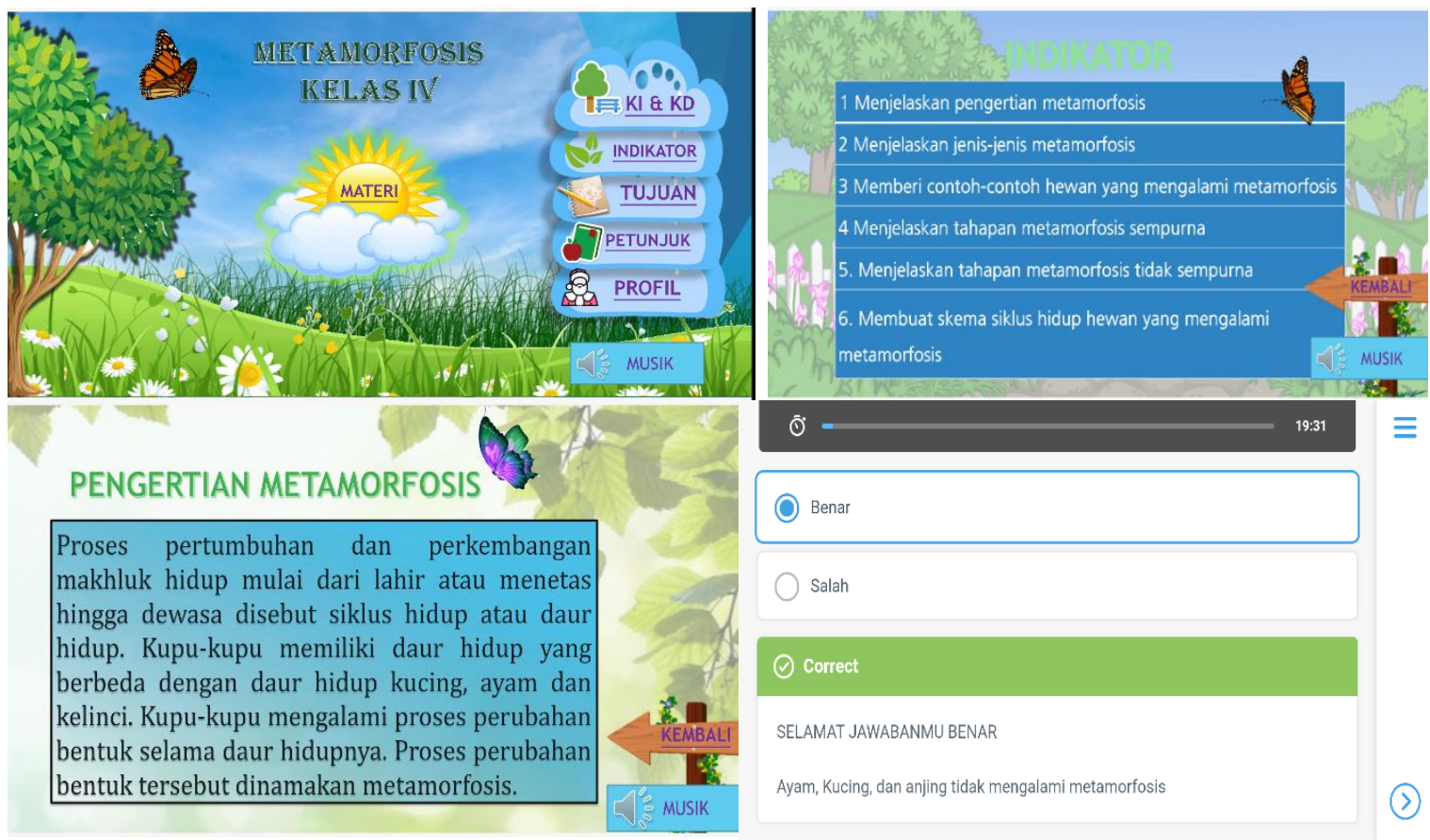

\section{Gambar 4.Tangkapan layar Aplikasi}

Validitas dari media pembelajaran ini dapat dilihat dari hasil angket yang diisi oleh para ahli dan siswa kelas IV. Uji coba kepada ahili isi mata pelajaran, ahli desain pembelajaran, ahli media pembelajaran, serta uji coba kepada siswa seperti uji coba perorangan dan uji coba kelompok kecil mendapatkan hasil sebagai berikut.

Berdasarkan uji coba yang dilakukan diperoleh hasil dari uji ahli isi mata pelajaran tematik pada muatan IPA dengan persentase 92,8\% berada pada kualifikasi sangat baik, sehingga produk pengembangan tersebut dinyatakan layak untuk digunakan. Hasil uji coba yang dilakukan diperoleh hasil dari uji ahli desain pembelajaran dengan persentase $92,8 \%$ berada pada kualifikasi sangat baik, sehingga produk pengembangan tersebut dinyatakan layak untuk digunakan dengan mempertimbangkan masukan yang diberikan. Uji coba yang dilakukan diperoleh hasil dari uji ahli media pembelajaran dengan persetase $93,1 \%$ berada pada kualifikasi sangat baik, sehingga produk pengembangan tersebut dinyatakan layak untuk digunakan dengan mempertimbangkan masukan yang diberikan. Uji coba perorangan yang dilakukan kepada 3 orang peserta didik kelas IV SD Negeri 3 Celuk dengan persentase $94,2 \%$ berada pada kualifikasi sangat baik, sehingga produk pengembangan tersebut dinyatakan layak untuk digunakan dengan mempertimbangkan masukan yang diberikan. Uji coba kelompok kecil persentase tingkat pencapaian yaitu $89,75 \%$ berada pada kualifikasi baik, sehigga produk pengembangan tersebut dinyatakan layak untuk digunakan dengan mempertimbangkan masukan yang diberikan. Hasil validitas tersebut disajikan secara singkatat pada tabel 1. 
Tabel 1. Hasil uji Validitas produk

\begin{tabular}{lccl}
\hline No & Subjek Uji Coba & Hasil Validitas (\%) & \multicolumn{1}{c}{ Kualifikasi } \\
\hline 1 & Uji Ahli Isi Mata Pelajaran & 92,8 & Sangat Baik \\
2 & Uji Ahli Desain Pembelajaran & 92,8 & Sangat Baik \\
3 & Uji Ahli Media Pembelajaran & 93,1 & Sangat Baik \\
4 & Uji Coba Perorangan & 94,2 & Sangat Baik \\
5 & Uji Coba Kelompok Kecil & 89,75 & Baik \\
\hline
\end{tabular}

Dari semua uji yang telah dilakukan kepada para ahli isi, desain, dan media pembelajaran, media ini mendapatkan beberapa masukan dan saran sebagai berikut. Dari ahli isi mata pelajaran media ini mendapat masukan untuk lebih memperinci indikator yang digunakan pada media pembelajaran. Ahli desain pembelajaran memberkan saran untuk meningkatkan dalam hal memfasilitasi/mengakomodasi keragaman gaya belajar masing-masing siswa yang berbeda-beda. Dan dari ahli desain media pembelajaran memberikan saran sebagai berikut. (1) Tombol volume diseting " on student demand". (2) Teks dan audio jangan double. (3) Berisikan pembahasan pada latihan. Sedangkan saat uji coba yang dilakukan kepada siswa baik uji coba perorangan dan uji coba kelompok kecil, media ini mendapatkan beberapa komentar darisiswa terkait kesan mereka terhadap media dan tidak ada yang memberi masuikan untuk perbaikan media.

Validitas media ini berdasarkan hasil uji ahli isi mata pelajaran mendapatkan hasil yang sangat bangus. Hal ini disebabkan karena media pembelajaran multimedia interaktif ini menyajikan isi materi pembelajaran yang sesuai dengan tuntutan kompetensi inti, kompetensi dasar, indikator dan tujuan yang diambil dari sumber yang bisa dipercaya. Media ini juga dilengkapi dengan evaluasi pembelajaran yang bersifat interaktif. Media dalam multimedia pembelajaran harus memperlihatkan karakteristik komponen lain, seperti : tujuan, materi, strategi dan juga evaluasi pembelajaran (Daryanto, 2016; Manurung \& Panggabean, 2020). Dalam menilai aspek isi/materi multimedia pembelajaran perlu memperhatikan kesesuaian antara isi materi dengan tujuan pembelajaran yang dituntut tercapai oleh peserta didik agar tercipta bahan ajar yang baik.

Validitas media ini berdasarkan hasil uji ahli desain pembelajaran mendapatkan hasil yang sangat bagus. Hal ini disebabkan karena desain dari media pembelajaran yang dikembangkan ini memberikan kontrol yang besar kepada peserta didik dalam pengoperasiannya. Pembelajaran multimedia umumnya dibuat berdasarkan besar kecilnya kontrol yang diberikan, peserta didik bisa diberdayakan dengan memberikan kontrol yang lebih besar (Daryanto, 2016; Riyanto \& Gunarhadi, 2017). Multimedia pembelajaran interaktif memiliki variasi fitur yang bisa disesuaikan dengan kebutuhan siswa dan dapat mengakomodasi siswa yang memiliki gaya belajar tipe visual, auditif, maupun kinestetik sehingga memudahkan siswa dalam belajar (Irwanto, Taufik, Hernawan, \& Rizal, 2019; Prasetya, Ade Yama Wahyu Nur, Dedi Kuswandi, 2018).

Validitas dari uji ahli media pembelajaran mendapatkan hasil yang sangat bagus. Hal itu dikarenakan media ini dirancang dengan menggunakan semua variasi media dari multiedia seperti gambar, teks, suara, animasi, suara, video, dan dikemas dengan menarik. Sesuai dengan pendapat yang menyatakan bahwa multimedia harus dapat memberikan kenyamanan kepada peserta didik dalam memberikan vasilitas dan motivasi dalam pembelajarannya dengan membuatnya mengandung beberapa komponen yang dapat mendukung pembelajaran peserta didiknya, elemen atau komponen yang terkandung dalam multimedia, antara lain Teks, Grafis/Foto, Audio, Video, dan Animasi (Ratih, Japa, \& Margunayasa, 2017; Wijoyo, 2018). Mutimedia interaktif materi pembelajaran disajikan atau dikemas secara menarik melalui penggabungan aspek animasi, suara, gambar, teks serta video (Pratama, dkk 2017). Media ini juga dilengkapi dengan kontrol pengguna media. Hal tersebut sejalan dengan pendapat Divayana, dkk (2016) yang menyatakan bahwa cara yang dapat digunakan untuk meningkatkan 
efektivitas dari proses pembelajaran adalah dengan membangun media pembelajaran yang bersifat interaktif. Media ini juga dapat memfasilitasi perbedaan gaya belajar siswa.

Validitas media ini berdasarkan uji coba kepada perserta didik mendapatkan hasil yang sangat bagus pada uji coba perorangan dan hasil bagus pada uji coba kelompok kecil. Hal ini sejalan dengan beberapa penelitian sebelumnya yang menguji multimedia pembelajaran interaktif. Hal ini disebabkan media pembelajaran yang dikembangkan menarik perhatian siswa dalam belajar sehingga meningkatkan hasil belajar siswa. Penelitian yang dilakukan oleh Diartha, Sudarma, \& Suwatra (2019b) menyatakan multimedia interaktif yang di kembangkan efektif untuk meningkatkan hasil belajar IPA peserta didik kelas V di SDN 2 Banjar Bali. Dengan demikian multimedia interaktif yang di kembangkan efektif untuk meningkatkan hasil belajar IPA peserta didik kelas V. Hasil media multimedia pembelajaran interaktif dapat meningkatkan hasil belajar peserta didik pada mata pelajaran IPS Terpadu sehingga multimedia pembelajaran interaktif tersebut dapat dikatakan efektif untuk digunakan dalam proses pembelajaran (Abdurrahman,dkk, 2020)

Media pembelajaran ini memiliki beberapa keunggulan dibandingkan dengan penlitian sebelumnya yang telah berhasil dilakukan. Pada media pembelajaran ini sudah ditambahkan dubbing tentang materi yang diberikan langsung oleh guru untuk memperjelas materi yang diberikan serta dapat menghadirkan kesan keberadaan guru dalam pembelajaran. Media yang dikembangkan ini juga dilengkapi video ilustrasi singkat agar ukuran media pembelajaran tidak terlalu besar, dapat memfasilititasi perbedaan gaya belajar siswa dan dapat menghasilkan kesan yang lebih nyata. Multimedia interaktif memilki beberapa keunggulan seperti (1) Multimedia yang digunakan dalam proses pembelajaran dapat melayani perbedaan gaya belajar, (2) Pembelajaran dengan multimedia akan lebih bermakna, (3) Multimedia dapat digunakan untuk pembelajaran individual, (4) Multimedia dapat memberikan wawasan yang lebih luas untuk mempelajari topik tertentu, (5) Multimedia dapat mengemas berbagai jenis materi pelajaran (Sanjaya, 2014). Pendapat lain juga mendukung hal tersebut dengan menyebutkan keunggulan multimedia interaktif seperti; siswa diberdayakan untuk mengendalikan lingkungan belajar, meningkatkan motivasi belajar siswa, terdapat umpan balik, kontrol sepenuhnya berada pada pengguna (Istiqlal, 2017; Kuswanto \& Walusfa, 2017).

Dari semua temuan yang telah disampaikan adapun implikasi dari penelitian ini yaitu media pembeljaran yang dikembangkan dapat digunakan untuk pembelajaran dalam jaringan khususnya dalam mengajarkan muatan materi IPA, karena media ini dapat menjadi pembelajaran yang sangat bervariatis dan interaktif sehingga siswa akan lebih tertarik dan tidak bosan mengikuti pembelajaran yang diberikan.

\section{Simpulan}

Hasil review ahli isi mata pelajaran, ahli media pembelajaran, uji coba perorangan dan uji coba kelompok kecil mendapatkan kualifikasi sangat baik. Media interaktif yang dikembangkan valid dan layak digunakan dalam pembelajaran. Media ini sangat baik untuk digunakan dalam pembelajaran IPA di sekolah dasar.

\section{Daftar Pustaka}

Abdurrahman, Jampel, I. N., \& Sudatha, I. G. W. (2020). Pengembangan Multimedia Pembelajaran Interaktif untuk Meningkatkan Hasil Belajar IPS. EDUTECH Universitas Pendidikan Ganesha, 8, 32-45. https://doi.org/http://dx.doi.org/10.23887/jeu.v8i1.27049

Adam, Steffi, D. (2015). Pemanfaatan Media Pembelajaran Berbasis Teknologi Informasi Bagi Siswa Kelas x SMA Ananda Batam. CBIS Journal, 2, 78-90. Retrieved from http://ejournal.upbatam.ac.id/index.php/cbis/article/view/400 
Akrim. (2018). Pengembangan Program Pembelajaran Tematik Terpadu Bagi Guru-Guru SD Muhammadiyah Di Kota Medan. Jurnal Prodikmas: Hasil Pengabdian Masyarakat, 2, 103-111. https://doi.org/https://doi.org/10.30596/jp.v2i2.2462

Ananda, R. dan F. (2018). Analisis Kemampuan Guru Sekolah Dasar Dalam Implementasi Pembelajaran Tematik di SD. Basicedu, 2, 11-21. https://doi.org/https://doi.org/10.31004/basicedu.v2i2.138

Anshory, I. (2020). Pembelajaran Tematik Integratif Pada Kurikulum 2013 di Kelas Rendah SD Muhammadiyah 07 Wajak. JINoP (Jurnal Inovasi Pembelajaran), 4 Nomor1, 3546. https://doi.org/https://doi.org/10.22219/jinop.v4i1.4936

Asto, P. dan. (2015). Pengembangan Media Pembelajaran Multimedia Interaktif Berbantuan Software Macromedia Flash Pada Kompetensi Dasar Menerapkan Macam-Macam Gerbang Dasar Rangkaian Logika di SMK Negeri 2 Bojonegoro. Jurnal Pendidikan Teknik Elektro, 4(1), 177-181. Retrieved from https://jurnalmahasiswa.unesa.ac.id/index.php/jurnal-pendidikan-teknikelektro/article/view/10423

Daryanto. (2016). Media Pembelajaran. yogyakarta: Gava Media.

Diartha, P. M. P., Sudarma, I. K., \& Suwatra, I. I. W. (2019a). Pengembangan Multimedia Berorientasi Pembelajaran Team Games Tournament Pada Mata Pelajaran IPA Kelas Iv Sekolah Dasar Mutiara Singaraja. Edutech Universitas Pendidikan Ganesha, 7(1), 1-11. https://doi.org/http://dx.doi.org/10.23887/jeu.v7i1.19969

Diartha, P. M. P., Sudarma, I. K., \& Suwatra, I. W. (2019b). Pengembangan Multimedia Berorientasi Pembelajaran Team Games Tournament Pada Mata Pelajaran IPA Kelas IV Sekolah Dasar Mutiara Singaraja. Edutech Universitas Pendidikan Ganesha, 7, 1-11. https://doi.org/http://dx.doi.org/10.23887/jeu.v7i1.19969

Divayana, Dewa Gede Hendra , P. Wayan Arta Suyasa, N. S. (2016). Pengembangan Media Pembelajaran Berbasis Web Untuk Matakuliah Kurikulum dan Pengajaran di Jurusan Pendidikan Teknik Informatika Universitas Pendidikan Ganesha. Jurnal Nasional Pendidikan Teknik Informatika (JANAPATI), 5(3), 149-157. https://doi.org/http://dx.doi.org/10.23887/janapati.v5i3.9922

Herayanti, L., Habibi, H., \& Fuaddunazmi, M. (2017). Pengembangan Media Pembelajaran Berbasis Moodle pada Matakuliah Fisika Dasar. Jurnal Cakrawala Pendidikan, 36(2), 210-219. https://doi.org/10.21831/cp.v36i2.13077

Irwanto, Taufik, Hernawan, \& Rizal. (2019). Efektivitas Multimedia Interaktif Dan Mobile Learning Dalam Meningkatkan Hasil Belajar Siswa Pada Mata Pelajaran Seni Budaya. Jurnal Pendidikan Dan Kajian Seni, 4(1). https://doi.org/http://dx.doi.org/10.30870/jpks.v4i1.6845.

Isdayanti, D. (2020). Pengembangan Media Pembelajaran Audio Visual Berbasis Adobe Flash Pada Materi Daur Hidup Hewan. JIPP (Jurnal IImiah Pendidikan Dan Pembelajaran, 4(2), 390-406. https://doi.org/http://dx.doi.org/10.23887/jipp.v4i2.27320

Istiqlal, M. (2017). Pengembangan Multimedia Interaktif dalam Pembelajaran Matematika. Jurnal Ilmiah Pendidikan Matematika, 2(2), 43-3. https://doi.org/https://doi.org/10.26877/jipmat.v2i1.1480

Kudisiah. (2018). Meningkatkan Hasil Belajar Ipa Materi Gaya Menggunakan Metode Demonstrasi Pada Siswa Kelas IV SDN Bedus Tahun Pelajaran 2017/2018. Jurnal IImiah Mandala Education, 4(2), 195-202. https://doi.org/http://dx.doi.org/10.36312/jime.v4i2.475

Kustandi, C., \& Darmawan, D. (2020). Pengembangan Media Pembelajaran. Prenada 
media.

Kuswanto, J., \& Walusfa, Y. (2017). Pengembangan Multimedia Pembelajaran pada Mata Pelajaran Teknologi Informasi dan Komunikasi Kelas VIII. Innovative Journal of Curriculum and Educational Technology IJCET, 6(2), 58-64. https://doi.org/https://doi.org/10.15294/ijcet.v6i2.19335

Lasminiasih, D. (2016). Perancangan Sistem Informasi Kredit Mikro Mahasiswa Berbasis Web. Jurnal Sistem Informasi (Journal of Information System), 8(1), 883-893. https://doi.org/https://doi.org/10.36706/jsi.v8i1.2957

Manurung, \& Panggabean. (2020). Improving Students' Thinking Ability In Physics Using Interactive Multimedia Based Problem Solving. Cakrawala Pendidikan, 39(2), 460470. https://doi.org/https://doi.org/10.21831/cp.v39i2.28205

Melianti, E. R. (2020). Pengembangan Media Pembelajaran Berbasis Multimedia Interaktif Menggunakan Macromedia Director Pada Materi Usaha Dan Energi Kelas X. Jurnal Kumparan Fisika, 3(1), 1-10. https://doi.org/https://doi.org/10.33369/jkf.3.1.1-10

Nugroho, Adam Satya Praba, Rahayuningsih, Margareta, Setiati, N. (2014). Efektifitas Pemanfaatan Penangaran kupu-kupu di UNNES Sebagai Sumber Belajar Materi Pertumbuhan dan Perkembangan Bagi Siswa SMP Negeri 24 Semarang. Unnes Journal of Biology Education, 3(1), 1-9. https://doi.org/https://doi.org/10.15294/jbe.v3i1.4149

Prasetya, Ade Yama Wahyu Nur, Dedi Kuswandi, S. A. (2018). Multimedia Interaktif pada Pembelajaran Tematik untuk Kelas IV Sekolah Dasar. Jurnal Pendidikan: Teori, Penelitian, Dan Pengembangan, 3(11), 1423-1427. https://doi.org/http://dx.doi.org/10.17977/jptpp.v3i11.11751

Pratama, I. W. A., Mahadewi, L. P. P., \& Suartama, I. K. (2017). Pengembangan Multimedia Interaktif Berbasis Model Vak Pada Mata Pelajaran IPA Siswa Kelas V Di SDN 2 Banjar Bali. $05, \quad$ 132-141. https://doi.org/http://dx.doi.org/10.23887/jeu.v5i1.20635

Puspitorini, Subali, \& Jumadi. (2014). Penggunaan Media Komik Dalam Pembelajaran IPA Untuk Meningkatkan Motivasi Dan Hasil Belajar Kognitif Dan Afektif. Cakrawala Pendidikan, 33(3), 413-420. Retrieved from https://journal.uny.ac.id/index.php/cp/article/view/2385/pdf

Rahmi, M. S. M., Budiman, M. A., \& Widyaningrum, A. (2019). Pengembangan Media Pembelajaran Interaktif Macromedia Flash 8 Pada Pembelajaran Tematik Tema Pengalamanku. International Journal Of Elementary Education, 3(2), 178-185. https://doi.org/10.23887/ijee.v3i2.18524

Ratih, i K. D. R., Japa, I. G. N., \& Margunayasa, I. G. (2017). Pengaruh Model Pembelajaran Numbered Head Together Berbantuan Multimedia Interaktif Terhadap Hasil Belajar IPA. MIMBAR PGSD Undiksha, 5(2), 1-9. https://doi.org/http://dx.doi.org/10.23887/jjpgsd.v5i2.10880

Riyanto, W. D., \& Gunarhadi, G. (2017). The Effectiveness of Interactive Multimedia in Mathematic Learning: Utilizing Power Points for Students with Learning Disability. IJPTE: International Journal of Pedagogy and Teacher Education, 1(1), 55-63. https://doi.org/10.20961/ijpte.v1i1.8400

Rusman. (2017). Belajar dan Pembelajaran Beroientasi Standar Proses Pendidikan. Jakarta: Kencana.

Sanjaya, W. (2014). Media Komunikasi Pembelajaran. jakarta: Kencana.

Supriyono. (2018). Pentingnya Media Pembelajaran Untuk Meningkatkan Minat Belajar 
Siswa SD. Edustream: Jurnal Pendidikan Dasar, 2(1), 43-48. Retrieved from https://journal.unesa.ac.id/index.php/jpd/article/view/6262

Susanto, A. (2015). Teori Belajar \& Pembelajaran. Jakarta: Prenadamedia Group.

Sutrisno. (2016). Berbagai Pendekatan Dalam Pendidikan Nilai Dan Pendidikan Kewarganegaraan. Jurnal Dimensi Pendidikan Dan Pembelajaran, 4(1). https://doi.org/. http://dx.doi.org/10.24269/dpp.v4i1.56.

Tegeh, D. (2014). Model Penelitian Pengembangan. Yokyakarta: Graha IImu.

Tias, I. W. U. (2017). Penerapan Model Penemuan Terbimbing Untuk Meningkatkan Hasil Belajar Ipa Siswa Sekolah Dasar. DWIJA CENDEKIA: Jurnal Riset Pedagogik, 1(1), 50-60. https://doi.org/10.20961/jdc.v1i1.13060

Wahyuni, H. T., Setyosari, P., \& Kuswandi, D. (2018). Perangkat Visualisasi Metamorfosis Kupu-kupu Menggunakan Animated Augmented Reality. Jurnal IImiah SISFOTENIKA, 8(1), 69-80. https://doi.org/http://dx.doi.org/10.30700/jst.v8i1.180

Wijanarko, Y. (2017). Model Pembelajaran Make a Match Untuk Pembelajaran Ipa Yang Menyenangkan. Taman Cendekia: Jurnal Pendidikan Ke-SD-An, 1(1), 52. https://doi.org/10.30738/tc.v1i1.1579

Wijoyo, A. (2018). Pengaruh Hasil Belajar Siswa Dengan Menggunakan Multi Media Pembelajaran Interaktif Untuk Sekolah Menengah Pertama dan Sekolah Menengah Atas. Jurnal Informatika Universitas Pamulang, 3(1), 46-55. https://doi.org/http://dx.doi.org/10.32493/informatika.v3i1.1519

Wulandari, Sudatha, \& Simamora. (2020). Pengembangan Pembelajaran Blended Pada Mata Kuliah Ahara Yoga Semester II di IHDN Denpasar. Jurnal Edutech Undiksha, 8(1), 1-15. https://doi.org/http://dx.doi.org/10.23887/jeu.v8i1.26459

Yuliati, Y. (2017). Literasi sains dalam pembelajaran IPA. Jurnal Cakrawala Pendas, 3(2). https://doi.org/http://dx.doi.org/10.31949/jcp.v3i2.592 